\title{
Chronic allergen challenge induces bronchial mast cell accumulation in BALB/c but not C57BL/6 mice and is independent of IL-9
}

\author{
Suzan Pae • Jae Youn Cho • Shanna Dayan • \\ Marina Miller • Alan D. Pemberton • David H. Broide
}

Received: 25 January 2010 / Accepted: 27 April 2010/Published online: 18 May 2010

(C) The Author(s) 2010. This article is published with open access at Springerlink.com

\begin{abstract}
As genetically engineered mutant mice deficient in single genes are usually generated on a C57BL/6 background, to study mast cell trafficking in mutant mice, we initially investigated whether mast cells accumulated in bronchi in C57BL/6 mice challenged with OVA allergen acutely or chronically for 1 to 3 months. The total number of bronchial mast cells were quantitated using toluidine blue staining in airways of different sizes, i.e., small $(<90 \mu \mathrm{m})$, medium $(90$ $155 \mu \mathrm{m})$, or large $(>150 \mu \mathrm{m})$ airways. Non-OVA challenged and acute OVA challenged mice (C57BL/6 and BALB/c) had no detectable bronchial mast cells. Chronic OVA challenge in $\mathrm{BALB} / \mathrm{c}$ mice for 1 or 3 months induced a significant increase in the number of bronchial mast cells in small-, medium-, and large-sized airways but minimal change in the number of bronchial mast cells in C57BL/6 mice. Both BALB/c and C57BL/6 mice developed significant lung eosinophilia following acute or chronic OVA challenge. Studies of IL-9deficient mice on a BALB/c background demonstrated a significant increase in the number of bronchial mast cells in IL-9-deficient mice suggesting that IL-9 was not required for the bronchial accumulation of mast cells. Overall, these studies demonstrate that the chronic OVA challenge protocol
\end{abstract}

S. Pae J. Y. Cho $\cdot$ S. Dayan · M. Miller • D. H. Broide Department of Medicine, University of California San Diego, San Diego, CA, USA

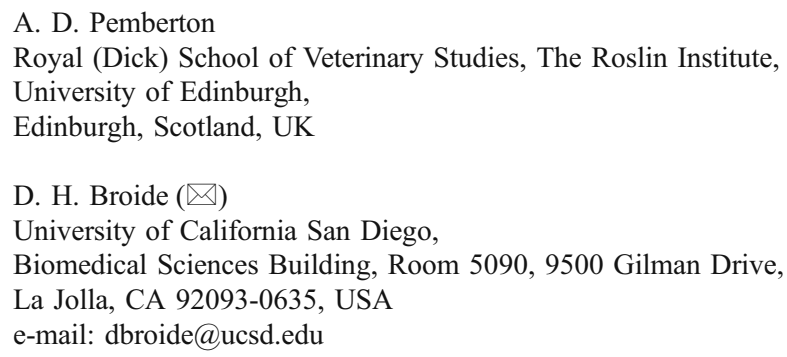

we have utilized in BALB/c mice provides a model to study the mechanism of bronchial mast cell accumulation and that bronchial mast cell accumulation in chronic OVA challenged mice is independent of IL-9 in this model.

Keywords BALB/c $\cdot$ C57BL/6 $\cdot$ Mast cell $\cdot$ Eosinophil

\section{Introduction}

Studies in mouse models of asthma (Kobayashi et al. 2000; Martin et al. 1993), as well as in human asthmatics (Black 2002; Bradding et al. 2006), have suggested an important role for mast cells in the pathogenesis of asthma. For example, studies in human asthmatics have demonstrated that the early phase response to inhalation of allergen is associated with increased levels of mast cell-derived mediators such as histamine and that this early phase response can be blocked with mast cell-directed antagonists such as antihistamines, or anti-IgE (Barrett and Austen 2009; Bradding et al. 2006; Brown et al. 2008; Galli et al. 2008, Milgrom et al. 1999). In addition to this evidence of mast cell involvement in human allergen challenge models of asthma, there is also evidence in spontaneous chronic asthma of ongoing mast cell degranulation (Broide et al. 1991), as well as evidence that mast cell-directed therapies such as anti-IgE reduce asthma exacerbations and allow for reductions by asthmatics of corticosteroid use (Milgrom et al. 1999).

Studies in mouse models of asthma using mutant mice deficient in mast cells have also provided evidence for an important role for mast cells in airway hyperreactivity (Kobayashi et al. 2000; Martin et al. 1993), eosinophilic airway inflammation (Williams and Galli 2000), and airway remodeling ( $\mathrm{Yu}$ et al. 2006). Special low-dose allergen sensitization protocols without adjuvant need to be utilized 
to demonstrate mast cell-dependent effects in mouse asthma models (Williams and Galli 2000; Yu et al. 2006) because of the small numbers of mast cells in the murine lung compared to the human lung. We have demonstrated that chronic inhalation OVA allergen challenge induces the recruitment of significant numbers of mast cells to the bronchial region in $\mathrm{BALB} / \mathrm{c}$ mice and that this accumulation of bronchial mast cells is significantly reduced in BALB/c mice pretreated with a TLR-9 agonist (Ikeda et al. 2003). As studies of mutant mice deficient in single genes provide an important tool to dissect the role of individual genes in contributing to accumulation of bronchial mast cells, in this study, we investigated whether bronchial mast cells accumulate in C57BL/6 mice (a common background strain of gene targeted mice) and then used IL-9-deficient mice to explore the role of IL-9, a cytokine associated with mast cell proliferation (Godfraind et al. 2009; Temann et al. 1988; Townsend et al. 2000) in contributing to bronchial mast cell accumulation following chronic OVA challenge for up to 3 months.

\section{Materials and methods}

\section{Induction of bronchial accumulation of mast cells}

The mouse model of OVA-induced accumulation of bronchial mast cells has previously been described (Ikeda et al. 2003). In brief, 8 - to 10-week-old female BALB/c mice ( $n=8 /$ group; Jackson Laboratory, Bar Harbor, ME, USA), C57BL/6 mice ( $n=8$ /group; Jackson Laboratory, Bar Harbor, ME, USA), or IL-9-deficient mice on a BALB/c background (kindly provided by Dr A McKenzie, UK; Townsend et al. 2000; $n=8$ mice/group) were immunized sc on days $0,7,14$, and 21 with $25 \mu \mathrm{g}$ of OVA (grade V, Sigma) adsorbed to $1 \mathrm{mg}$ of alum (Aldrich) in $200 \mu \mathrm{l}$ of normal saline. For the acute OVA protocol, intranasal OVA challenges $(20 \mu \mathrm{g} / 50 \mu \mathrm{l}$ in PBS) were administered on days 27,29 , and 31 under isoflurane (Vedco, St. Joseph, MO, USA) anesthesia, and mice were sacrificed $24 \mathrm{~h}$ later. LPS levels in the $20 \mu \mathrm{g}$ of OVA administered intranasally were $1.4 \mathrm{ng}$ as measured by limulus amebocyte lysate assay according the manufacturer instructions (Lonza, Walkersville, MD, USA; sensitivity of LPS assay $0.01 \mathrm{ng} / \mathrm{ml}$ ). For the chronic OVA protocol, mice were sensitized and challenged intranasally as described for the 31day acute OVA protocol. Intranasal OVA challenges were then repeated twice a week for 1 to 3 months. Age- and sexmatched control mice were sensitized but not challenged with OVA during the study. Mice were sacrificed $24 \mathrm{~h}$ after the final acute or chronic OVA challenge and bronchoalveolar lavage (BAL) fluid was collected by lavaging the lung with $1 \mathrm{~mL}$ PBS via a tracheal catheter (Ikeda et al. 2003). Lungs from the different experimental groups were processed as a batch for toluidine blue staining under identical conditions. Stained slides were all quantified under identical light microscope conditions, including magnification $(\times 20)$, gain, camera position, and background illumination. All animal experimental protocols were approved by the University of California, San Diego Animal Subjects Committee.

Toluidine blue staining and quantitation of bronchial mast cells

Quantitation of bronchial mast cells was performed as previously described in this laboratory on formalin-fixed paraffin-embedded lungs (Ikeda et al. 2003). In brief, the paraffin-embedded lungs were sectioned at $5 \mu \mathrm{m}$ onto microscope slides, and the paraffin was removed using alcohol gradients and Citrosolv (Fisher, Pittsburgh, PA, USA). The lung sections were stained with $1 \%$ toluidine blue (Sigma-Aldrich) to detect metachromatic mast cell cytoplasmic granules as previously described in this laboratory (Ikeda et al. 2003). Light microscopy was used to count the number of mast cells per airway in lung sections. To standardize the quantification of bronchial mast cells, airways were characterized by size using a light microscope (Leica DMLS, Leica Microsystems) attached to an image analysis system (Image-Pro plus, Media Cybernetics) as large $(125-250 \mu \mathrm{m})$, medium (60$125 \mu \mathrm{m})$, or small $(<60 \mu \mathrm{m})$ by measuring the diameter of the long axis of the airway as previously described (Ikeda et al. 2003). The bronchial area was defined as the circumferential area extending from the lumenal surface of the airway epithelium to $8 \mu \mathrm{m}$ beneath the basement membrane of the airway epithelium in small airways, to $15 \mu \mathrm{m}$ beneath the basement membrane of the airway epithelium in medium-sized airways, and to $20 \mu \mathrm{m}$ beneath the basement membrane of the airway epithelium in large airways (Ikeda et al. 2003). The distance beneath the basement membrane chosen to define the bronchial space was based on pilot experiments demonstrating the area in which the majority of nonmast cell bronchial inflammatory cells were recruited after OVA allergen challenge. The number of mast cells per airway was counted in ten randomly selected airways of each size in each mouse. In selected experiments, we used immunohistochemistry on lung sections as previously described in this laboratory (Ikeda et al. 2003) to detect the mouse mucosal mast cell granule protease mMCP-1 with an antimMCP-1 Ab (Pemberton et al. 2003). A species and isotype control $\mathrm{Ab}$ was used in these experiments.

\section{Statistical analysis}

Data were collected and analyzed with $T$ tests using Prism statistical software. Values of $p<0.05$ were considered 
statistically significant. Results are expressed as the mean \pm SEM unless otherwise indicated.

\section{Results}

Mast cells accumulate following 1 month of chronic OVA antigen challenge in small, medium, and large airways of $\mathrm{BALB} / \mathrm{c}$ but not $\mathrm{C} 57 \mathrm{BL} / 6$ mice

Bronchial mast cells were not detected in non-OVAchallenged mice in small, medium, or large airways in either $\mathrm{BALB} / \mathrm{c}$ or $\mathrm{C} 57 \mathrm{BL} / 6$ mice by toluidine blue staining or immunostaining with an anti-mMCP-1 Ab (Fig. 1). However, in BALB/c mice subjected to 1 month of chronic OVA challenge, significantly increased numbers of mast cells were detected compared to non-OVA-challenged $\mathrm{BALB} / \mathrm{c}$ mice in small airways $(0.7 \pm 0.7$ vs $0 \pm 0$ mast cells/airway; $p=0.03$ ) (Fig. 2a), medium-sized airways $(1.3 \pm 0.5$ vs $0 \pm 0$ mast cells/airway; $p<0.0001$; Fig. 2b), and large-sized airways ( $1.0 \pm 0.5$ vs $0 \pm 0$ mast cells/airway; $p=0.0003$; Fig. 2c). As previously reported (Ikeda et al.
2003), the majority of bronchial mast cells in chronic OVA challenged mice were intraepithelial ( $>95 \%$; Fig. 1b, d). Immunostaining with an anti-mMCP-1 Ab demonstrated similar numbers of mMCP-1-positive and toluidine bluepositive mast cells in lung sections, as well as a similar distribution of toluidine blue-positive cells and mMCP-1positive cells in airway epithelium (Fig. 1). In contrast to chronically OVA-challenged BALB/c mice which accumulated bronchial mast cells in response to chronic OVA challenge for 1 month, chronic OVA-challenged C57BL mice did not accumulate any mast cells at 1 month in either small airways $(0 \pm 0$ mast cells/airway; Fig. $2 \mathrm{a})$, mediumsized airways ( $0 \pm 0$ mast cell/airway; Fig. 2b), or largesized airways ( $0 \pm 0$ mast cells/airway; Fig. $2 \mathrm{c})$.

Chronic OVA challenge for 3 months induces further increase in mast cell accumulation in small-, medium-, and large-sized airways of BALB/c but not C57BL/6 mice

BALB/c mice subjected to 3 months of chronic OVA challenge had increased numbers of mast cells compared to 1 month chronic OVA-challenged BALB/c

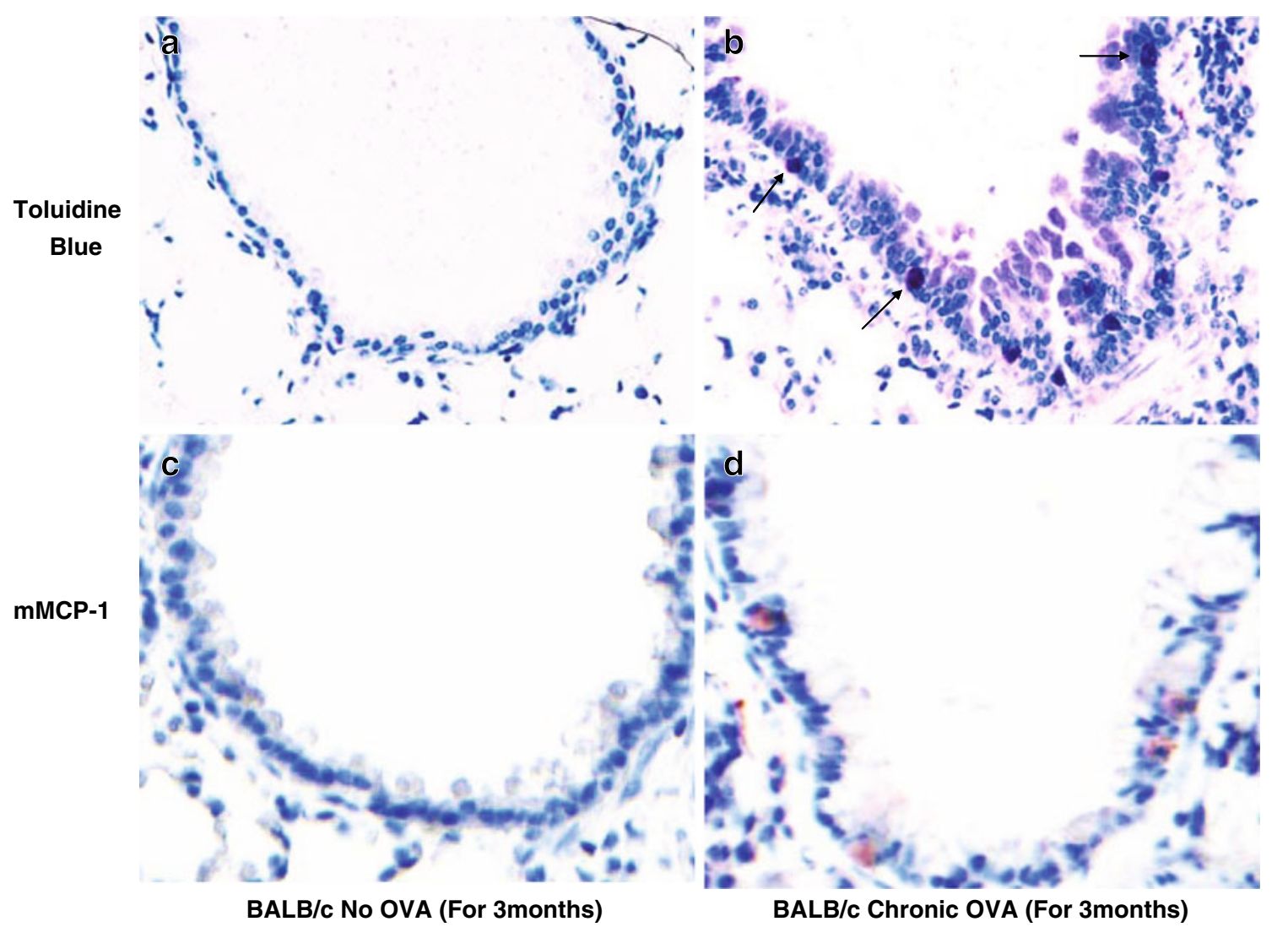

Fig. 1 Airway mast cell detection. Lung sections were stained with toluidine blue $(1 \%)$ or immunostained with an anti-mMCP-1 Ab to detect mast cells. No toluidine blue-positive mast cells were detected in non-OVA-challenged BALB/c mice (a), whereas several toluidine blue-positive mast cells (arrows) were detected in the airway epithelium in BALB/c mice chronically challenged with OVA for 3 months (b). Similarly, no mMCP-1-positive mast cells were detected in non-OVA-challenged BALB/c mice (c), whereas several mMCP-1positive mast cells were detected in the airway epithelium in BALB/c mice chronically challenged with OVA for 3 months (d) 
a

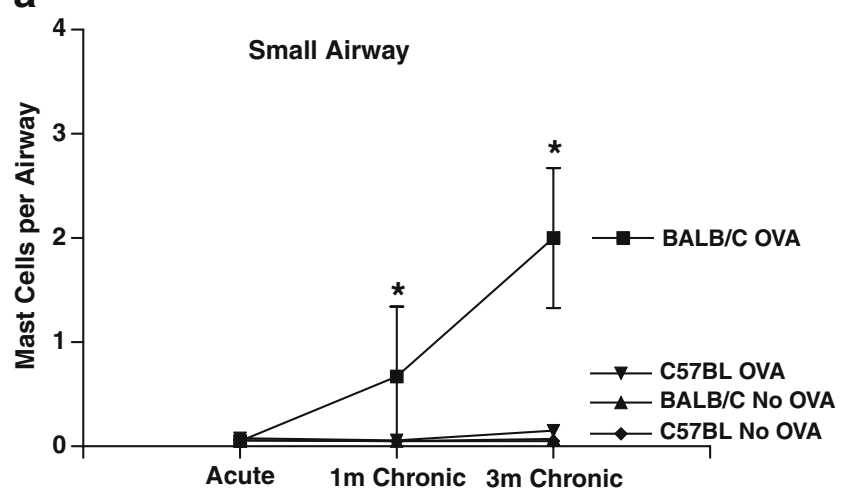

b
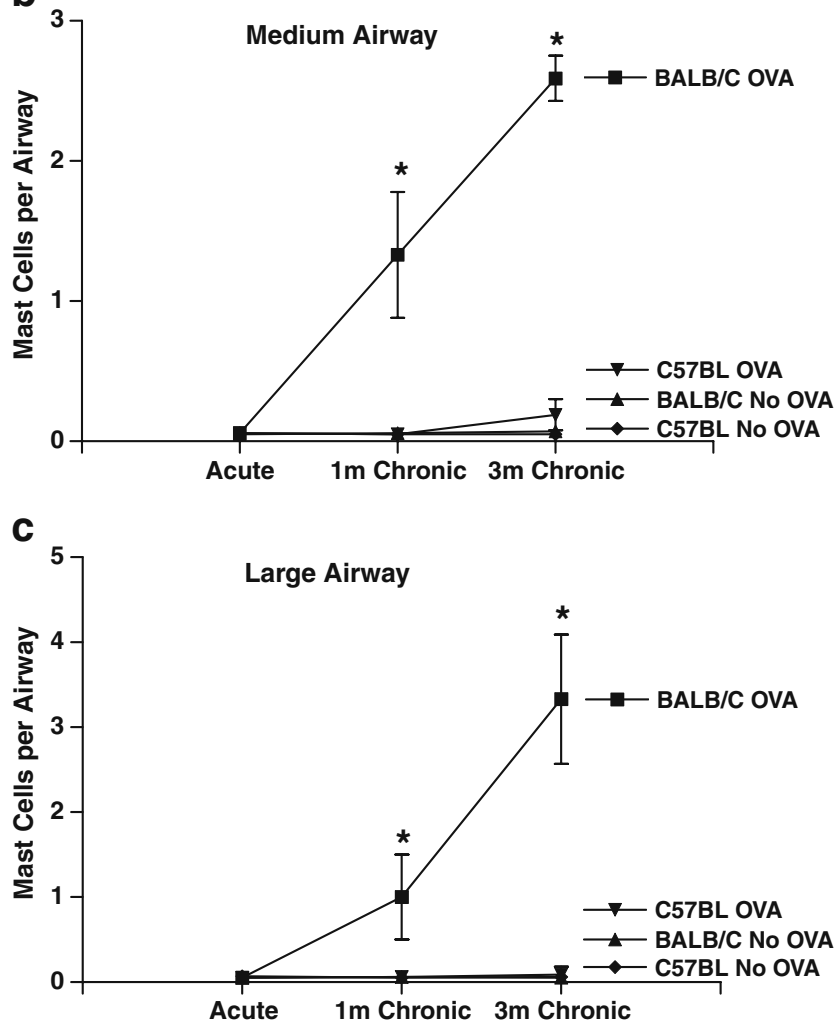

Fig. 2 Quantitation of airway mast cells in BALB/c and C57BL/6 mice following acute and chronic OVA challenge. BALB/c or C57BL/ 6 mice were challenged with OVA acutely or chronically for 1 or 3 months. Non-OVA-challenged BALB/c or C57BL/6 mice served as controls. The number of toluidine blue-positive bronchial mast cells in small airways (a), medium-sized airways (b), and large airways (c) were quantitated. Acute OVA challenge induced no increase in bronchial mast cells in BALB/c or $\mathrm{C} 57 \mathrm{BL} / 6$ mice. Chronic OVA challenge in $\mathrm{BALB} / \mathrm{c}$ mice induced a significant increase in bronchial mast cells at 1 month in small $(p=0.03 ; \mathbf{a})$, medium $(p<0.0001 ; \mathbf{b})$, as well as large airways $(p=0.0003 ; \mathbf{c})$. Similarly, 3 months of chronic OVA challenge in $\mathrm{BALB} / \mathrm{c}$ mice induced a significant increase in bronchial mast cells in small ( $p<0.05$; Fig. 2a), medium $(p<0.001$; Fig. $2 \mathrm{~b}$ ), as well as large airways $(p=0.003 ; \mathbf{c})$. In contrast, chronic OVA challenge in C57BL/6 mice for 1 or 3 months did not increase the number of bronchial mast cells in small (a), medium (b), or large airways (c; $n=8 \mathrm{mice} /$ group) mice in small airways $(2.0 \pm 1.0$ vs $0.7 \pm 0.7$ mast cells/

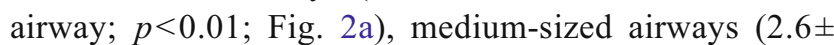
0.5 vs $1.3 \pm 0.5$ mast cells/airway; $p<0.01$; Fig. $2 b$ ), and large-sized airways $(3.3 \pm 0.8$ vs $1.0 \pm 0.5$ mast cells/ airway; $p<0.01$; Fig. $2 \mathrm{c}$ ). In contrast to the increased numbers of bronchial mast cells in $\mathrm{BALB} / \mathrm{c}$ mice chronically challenged with OVA (mean of 2.0, 2.6, and 3.3 mast cells/small, medium, or large airway), C57BL/6 mice subjected to 3 months of chronic OVA challenge had minimal bronchial mast cell accumulation, i.e. , $<0.2$ mast cell/airway (small airway $0.2 \pm 0.5$ mast cells/airway (Fig. 2a); medium-sized airway $0.2 \pm 0.1$ mast cells/ airway (Fig. 2b); large-sized airway $0.1 \pm 0.1$ mast cells/ airway; Fig. 2c).

BAL eosinophil accumulation in BALB/c and C57BL/6 mice

Non-OVA-challenged mice (either BALB/c or C57BL/6 mice) had no eosinophils in BAL (Fig. 3). In contrast, acute OVA challenge (Fig. 3a), or chronic OVA challenge for 1 month (Fig. 3b) or 3 months (Fig. 3c), induced significant BAL eosinophilia in both BALB/c and C57BL/6 mice. The number of BAL eosinophils was the highest following acute OVA challenge and decreased with chronic OVA challenge in both BALB/c and C57BL/6 mice. The numbers of BAL eosinophils were higher in C57BL/6 compared to BALB/c mice challenged acutely or chronically with OVA. The acute and chronic OVA protocols induce minimal BAL neutrophil responses in both strains of mice (data not shown).

Studies of mast cell accumulation in IL-9-deficient mice on a BALB/c background

As our studies demonstrated that studying mast cell accumulation in gene-deficient mice on a C57BL/6 background would be challenging to interpret (based on the very low levels of mast cell accumulation in C57BL/6 mice the background strain of most gene-deficient mice), we examined mast cell accumulation in IL-9-deficient mice on a BALB/c background for at least 12 generations.

\section{Acute OVA challenge (WT vs IL-9 deficient)}

Bronchial mast cells were not detected in non-OVA or acute OVA-challenged mice in either BALB/c or IL-9-deficient mice in small (Fig. 4a), medium (Fig. 4b), or large airways (Fig. 4c).

\section{Chronic OVA challenge for 1 month (WT vs IL-9 deficient)}

Following 1 month of chronic OVA challenges, there was a similar significant accumulation of bronchial mast cells in 
a

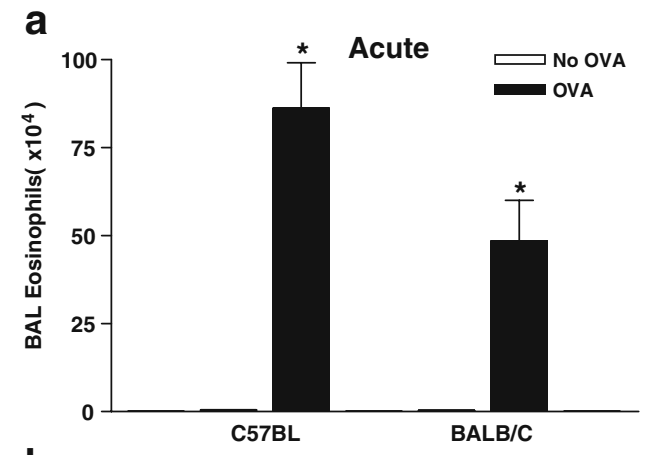

b

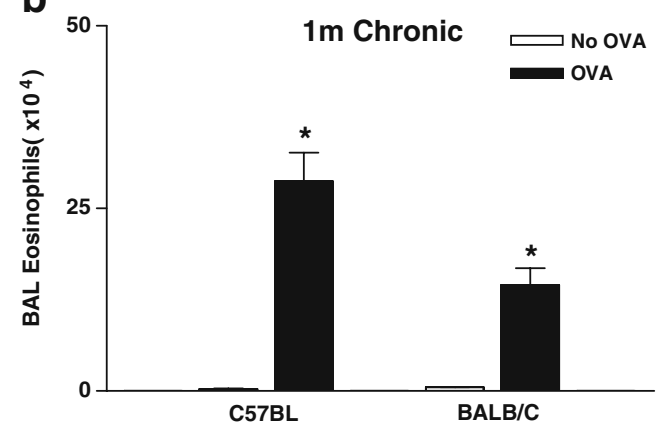

C

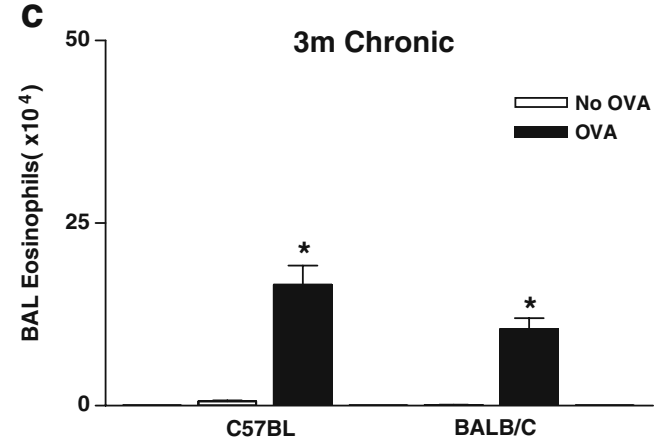

Fig. 3 Quantitation of BAL eosinophils in BALB/c and C57BL/6 mice following acute and chronic OVA challenge. $\mathrm{BALB} / \mathrm{c}$ or $\mathrm{C} 57 \mathrm{BL} / 6$ mice were challenged with OVA acutely or chronically for 1 or 3 months. NonOVA-challenged BALB/c or C57BL/6 mice served as controls. The number of Wright Giemsa-positive eosinophils in BAL were quantitated. Acute OVA challenge induced a significant increase in BAL eosinophils in C57BL/6 $(p<0.001)$ and BALB/c mice $(p<0.01 ; \mathbf{a})$. Chronic OVA challenge in $\mathrm{C} 57 \mathrm{BL} / 6$ mice induced a significant increase in $\mathrm{BAL}$ eosinophils at 1 month $(p<0.01 ; \mathbf{b})$ and at 3 months $(p<0.05$; c). Similarly, in BALB/c, chronic OVA challenge induced a significant increase in BAL eosinophils at 1 month $(p<0.01 ; \mathbf{b})$ and at 3 months $(p<0.05 ; \mathbf{c} ; n=8$ mice/group $)$

both IL-9-deficient as well as in BALB/c WT mice in the small airways $(1.1 \pm 0.3$ vs $0.7 \pm 0.2$ mast cells/airway; Fig. 4a), medium-sized airways ( $1.0 \pm 0.3$ vs $0.6 \pm 0.2$ mast cells/airway; Fig. 4b), and large airways ( $1.8 \pm 1.1$ vs $2.0 \pm$ 0.7 mast cells/airway; IL-9 KO chronic OVA vs WT chronic OVA; Fig. 4c). There were no statistically significant differences in mast cell accumulation in the small, medium, or large airways between IL-9 KO vs WT mice following 1 month chronic OVA challenge. a

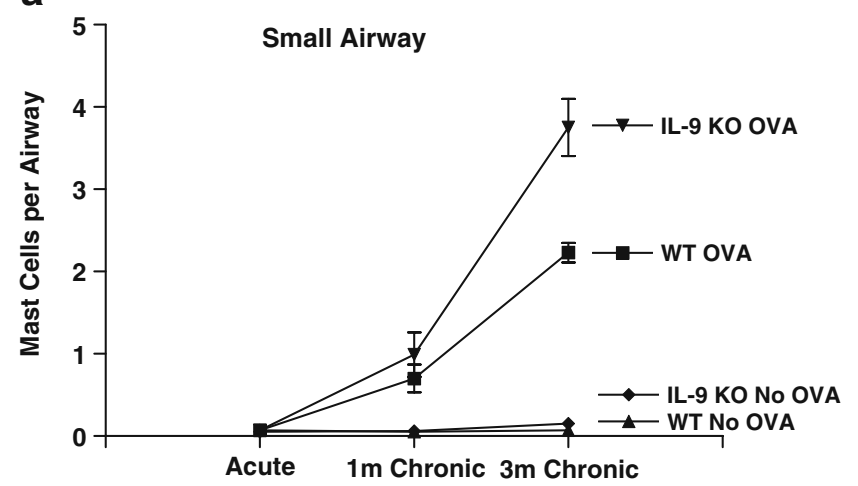

b

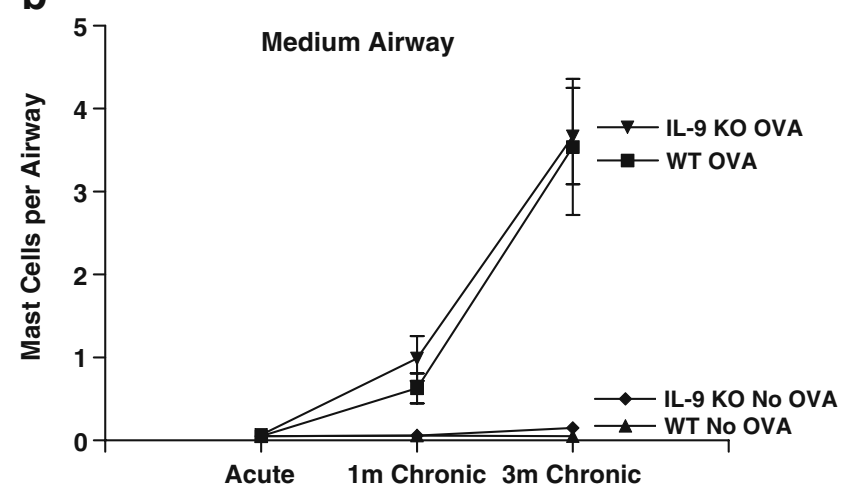

C

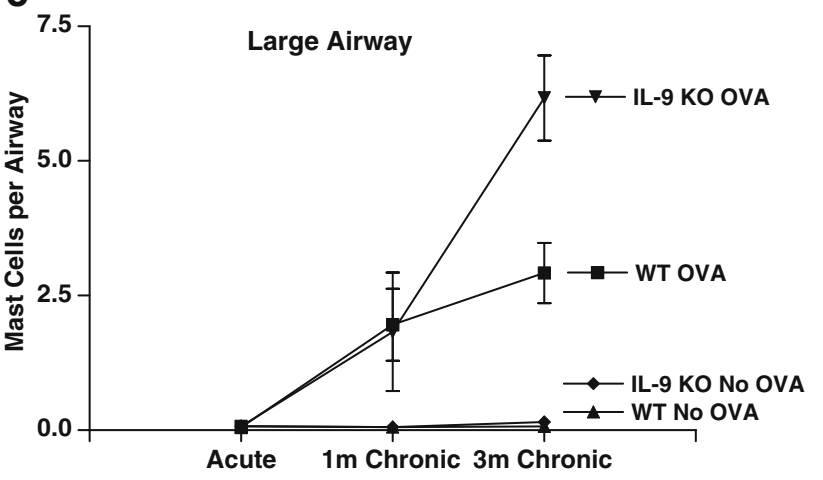

Fig. 4 Quantitation of airway mast cells in WT and IL-9-deficient mice following acute and chronic OVA challenge. BALB/c (referred to as WT) or IL-9-deficient mice on a BALB/c background (referred to as IL-9 KO) were challenged with OVA acutely or chronically for 1 or 3 months. Non-OVA-challenged WT or IL-9 KO mice served as controls. The number of toluidine blue-positive bronchial mast cells in small airways (a), medium-sized airways (b), and large airways (c) were quantitated. Acute OVA challenge induced no increase in bronchial mast cells in WT or IL-9 KO mice. There was no difference in the number of bronchial mast cells in chronic OVA allergenchallenged IL-9 KO compared to WT mice at 1 month in the small airways (a), medium airways (b), or large airways (c). At 3 months, there was also no difference in the number of bronchial mast cells in chronic OVA allergen challenged IL-9 KO compared to WT mice in medium-sized airways ( $p=\mathrm{ns}$; b), but there was an increase in the number of mast cells in the small airways $(p<0.05$; a) and large airways $(p<0.01 ; \mathbf{c})$ of IL-9 KO mice compared to WT mice $(n=$ $8 \mathrm{mice} /$ group) 
Chronic OVA challenge for 3 months (WT vs IL-9 deficient)

The number of mast cells in the small airways $(p=0.05)$ (Fig. 4a) and large airways ( $p=0.01$; Fig. 4b) of IL-9deficient mice challenged chronically with OVA allergen for 3 months was more than that of WT mice, while a similar number of bronchial mast cells was noted in the medium-sized airways of IL-9-deficient and WT mice ( $3.7 \pm 0.6$ vs $3.5 \pm 0.8$ mast cells/airway; $p=n s$; Fig. $4 \mathrm{~b})$.

\section{Discussion}

In this study, we have demonstrated that chronic allergen challenge induces a significant accumulation of mast cells in the bronchial region in BALB/c mice but did not induce a similar significant increase in bronchial mast cell number in $\mathrm{C} 57 \mathrm{BL} / 6$ mice. Interestingly, both BALB/c and C57BL/6 mice developed significant BAL eosinophilia following acute or chronic OVA challenge, suggesting that the significantly reduced numbers of bronchial mast cells in chronic OVA challenged C57BL/6 mice was not due to an impaired response by all inflammatory cells to the chronic OVA allergen challenge. The number of mast cells recruited to the airway in chronic OVA-challenged C57BL/6 mice (approximately 0.2 mast cells/hpf) is not significantly different from that noted in non-OVA-challenged mice ( 0 mast cells/hpf) and 10-15-fold less than that observed in chronic OVA-challenged BALB/c mice (approximately 2 to $3 / \mathrm{hpf}$ at 3 months). Thus, performing studies of the accumulation of bronchial mast cells in mutant mice on a C57BL/6 background would be difficult to interpret based on the very limited mast cell response in C57BL/6 mice to chronic administration of allergen. To investigate whether IL-9 contributes to the accumulation of bronchial mast cells following chronic allergen challenge, we therefore used IL9-deficient mice on a BALB/c background. These studies demonstrated that the bronchial accumulation of mast cells in chronic OVA-allergen-challenged mice for 1 or 3 months was IL-9 independent in small-, medium-, or large-sized airways.

Mouse strain specific differences in airway hyperreactivity and Th2 responses have been noted in models of acute asthma (Tumes et al. 2007; Walsh et al. 2008; Zhu and Gilmour 2009) and models of airway remodeling (Hirota et al. 2009; Shinagawa and Kojima 2003; Van Hove et al. 2009). Our study extends this observation of strain-specific differences in mouse models of asthma to differences in the ability to recruit mast cells to the bronchial region in $\mathrm{BALB} / \mathrm{c}$ vs $\mathrm{C} 57 \mathrm{BL} / 6$ mice in the model of OVA-induced allergic airway inflammation tested. This indicates that, in this asthma model, $\mathrm{BALB} / \mathrm{c}$ mice are likely to be superior to $\mathrm{C} 57 \mathrm{BL} / 6$ mice for studies of mast cell trafficking in gene-targeted mice. In contrast to the increased numbers of bronchial mast cells that occurs with time in chronic vs acute OVA models in BALB/c mice, our studies demonstrate that BAL eosinophil responses are the highest following acute OVA challenge and decrease with chronic exposure in both BALB/c and C57BL/6 mice. We have previously reported similar observations regarding lung eosinophil responses in both BALB/c (Cho et al. 2004a) and C57BL/6 mice (Cho et al. 2004b) subjected to chronic OVA challenge. Both $\mathrm{C} 57 \mathrm{BL} / 6$ and BALB/c mice develop significant airway remodeling with chronic OVA challenge, with $\mathrm{C} 57 \mathrm{BL} / 6$ tending to develop slightly higher levels of airway remodeling compared to $\mathrm{BALB} / \mathrm{c}$ mice (Cho et al. 2004a, b).

Our studies also demonstrated that IL-9-deficient mice on a $\mathrm{BALB} / \mathrm{c}$ background recruit mast cells to the small-, medium-, and large-sized airways as efficiently as wild-type mice. The potential for IL-9 to be a mast cell growth factor has been recognized in studies of IL-9 transgenic mice which have significantly increased levels of mast cells in various tissues including the lung (Godfraind et al. 2009; Temann et al. 1988). Studies of IL-9-deficient mice infected with schistosomiasis have also demonstrated the importance of IL-9 to pulmonary mastocytosis following acute but not chronic challenge (Townsend et al. 2000). In a model of acute OVA challenge, the number of mast cell precursor colonies in the digested lungs of IL-9-deficient mice on a BALB/c background was reduced (Jones et al. 2009). Differences in the results from these studies may relate to differences in requirements for IL-9 in the mouse models used (i.e., transgenic, schistosoma antigen, acute vs chronic allergen exposure), and differences in requirements for IL-9 depending upon the mast cells quantitated (mast cell precursor vs mature mast cell), or differences in requirements for IL-9 depending upon the localization of the mast cell in the lung (mast cells precursors were quantitated from whole lung digests, whereas mature mast cells were quantitated in small, medium, and large airways). Our study demonstrates that, with chronic allergen challenge, bronchial mast cells can accumulate in an IL-9-independent manner. Studies with these IL-9-deficient mice in an acute OVA challenge asthma model (McMillan et al. 2002) have also demonstrated that IL-9 is not required for the development of mucus, eosinophilic inflammation, IgE, Th2 cytokines, or airway responsiveness suggesting like in our study that other allergen-induced mediators can act in a compensatory fashion. Mast cells can increase in number in response to a variety of mediators other than IL-9 which are expressed following allergen challenge including cytokines that induce mast cell proliferation, i.e., IL-3 (Razin et al. 1984), IL-4 (Mossman et al. 1986), stem-cell factor (Zsebo et al. 1990), and chemokines that may recruit mast cells to the lung (Palmqvist et al. 2007). The increased numbers of bronchial 
mast cells in IL-9-deficient mice following 3 months of chronic OVA challenge could be due to compensatory increased levels of these or other mast cell growth factors at this time point. Further studies are needed to determine whether neutralizing these cytokines and/or chemokines selectively or in combination inhibits the chronic allergen induced bronchial accumulation of mast cells.

In summary, in this study, we have demonstrated that investigation of recruitment of mast cells to the airway in the mouse are best studied in BALB/c mice rather than in C57BL/6 mice. In addition, if studies of mast cell recruitment to the lung are performed in gene-targeted mice, the studies should be performed in mutant mice on a BALB/c background. Using this approach with IL-9deficient mice on a BALB/c background, we have demonstrated that bronchial mast cell accumulation in chronic allergen-challenged mice is IL-9 independent underscoring the potential utility of this model to studies of mast cell recruitment to the airway in mutant mice on a $\mathrm{BALB} / \mathrm{c}$ background.

Acknowledgments This study was supported by NIH grants AI 38425, AI 70535, and AI 72115 (DHB). Dr. Pae was supported by an NIH T32 grant AI 07469 as well an American Academy of Asthma Allergy Immunology/GSK postdoctoral fellowship award.

Conflict of interest The authors declare that they have no conflict of interest.

Open Access This article is distributed under the terms of the Creative Commons Attribution Noncommercial License which permits any noncommercial use, distribution, and reproduction in any medium, provided the original author(s) and source are credited.

\section{References}

Barrett NA, Austen KF (2009) Innate cells and T helper 2 cell immunity in airway inflammation. Immunity 31:425-437. doi:10.1016/j.immuni.2009.08.014

Black J (2002) The role of mast cells in the pathophysiology of asthma. N Engl J Med 346:1742

Bradding P, Walls AF, Holgate ST (2006) The role of the mast cell in the pathophysiology of asthma. J Allergy Clin Immunol 117:1277-1284. doi:10.1016/j.jaci.2006.02.039

Broide DH, Gleich GJ, Cuomo AJ, Coburn DA, Federman EC, Schwartz LB, Wasserman SI (1991) Evidence of ongoing mast cell and eosinophil degranulation in symptomatic asthma airway. J Allergy Clin Immunol 88:637. doi:10.1016/0091-6749(91)90158-K

Brown JM, Wilson TM, Metcalfe DD (2008) The mast cell and allergic diseases: role in pathogenesis and implications for therapy. Clin Exp Allergy 38:4-18. doi:10.1111/j.1365-2222.2007.02886.x

Cho JY, Miller M, Baek KJ, Han JW, Nayar J, Lee SY, McElwain K, McElwain S, Friedman S, Broide DH (2004a) Inhibition of airway remodeling in IL-5-deficient mice. J Clin Invest 113:551560. doi:10.1172/JCI200419133

Cho JY, Miller M, Baek KJ, Han JW, Nayar J, Rodriguez M, Lee SY, McElwain K, McElwain S, Raz E, Broide DH (2004b)
Immunostimulatory DNA inhibits transforming growth factorbeta expression and airway remodeling. Am J Respir Cell Mol Biol 30:651-661. doi:10.1165/rcmb.2003-0066OC

Galli SJ, Grimbaldeston MA, Tsai M (2008) Immunomodulatory mast cells: negative, as well as positive, regulators of immunity. Nat Rev Immunol 8:478-486. doi:10.1038/nri2327

Godfraind C, Louahed J, Faulkner H, Vink A, Warnier G, Grencis R, Renauld JC (2009) Intraepithelial infiltration by mast cells with both connective tissue-type and mucosal-type characteristics in gut, trachea, and kidneys of IL-9 transgenic mice. J Immunol 160:3989-3996

Hirota JA, Ask K, Fritz D, Wllis R, Wattie J, Richards CD, Labiris R, Kolb M, Inman MD (2009) Role of STAT6 and SMAD2 in a model of chronic allergen exposure: a mouse strain comparison study. Clin Exp Allergy 39:147-158. doi:10.1111/j.13652222.2008.03109.x

Ikeda RK, Miller M, Nayar J, Walker L, Cho JY, McElwain K, McElwain S, Raz E, Broide DH (2003) Accumulation of peribronchial mast cells in a mouse model of ovalbumin allergen induced chronic airway inflammation: modulation by Immunostimulatory DNA sequences. J Immunol 171:48604867

Jones TG, Hallgren J, Humbles A, Burwell T, Finkelman FD, Alcaide P, Austen KF, Gurish MF (2009) Antigen-induced increases in pulmonary mast cell progenitor numbers depend on IL-9 and CD1s-restricted NKT cells. J Immunol 183:5251-5260. doi:10.4049/jimmunol.0901471

Kobayashi T, Miura T, Haba T, Sato M, Serizawa I, Nagai H, Ishizaka $\mathrm{K}$ (2000) An essential role of mast cells in the development of airway hyperresponsiveness in a murine asthma model. J Immunol 164:3855

Martin TR, Takeishi T, Katz HR, Austen KF, Drazen JM, Galli SJ (1993) Mast cell activation enhances airway responsiveness to methacholine in the mouse. J Clin Invest 91:1176. doi:10.1172/ JCI116277

McMillan SJ, Bishop B, Townsend MJ, McKenzie AN, Lloyd CM (2002) The absence of interleukin 9 does not affect the development of allergen-induced pulmonary inflammation nor airway hyperreactivity. J Exp Med 195:51-57. doi:10.1084/ jem.20011732

Milgrom H, Fick RB Jr, Su JQ, Reimann JD, Bush RK, Watrous ML, Metzger WJ (1999) Treatment of allergic asthma with monoclonal anti-IgE antibody. rhuMAb-E25 Study Group. N Engl J Med 341:1966-1973

Mosmann TR, Bond MW, Coffman RL, Ohara J, Paul WE (1986) Tcell and mast cell lines respond to B-cell stimulatory factor 1 . Proc Natl Acad Sci USA 83:5654-5658

Palmqvist C, Wardlaw AJ, Bradding P (2007) Chemokines and their receptors as potential targets for the treatment of asthma. $\mathrm{Br} \mathrm{J}$ Pharmacol 151:725-736. doi:10.1038/sj.bjp.0707263

Pemberton AD, Brown JK, Wright SH, Knight PA, McPhee ML, Forse PA, Miller HRP (2003) Purification and characterization of mouse mast cell proteinase- 2 and the differential expression and release of mouse mast cell proteinase- 1 and -2 in vivo. Clin Exp Allergy 33:1005-1012. doi:10.1046/j.1365-2222.2003. 01720

Razin E, Jn I, Seldin D, Mencia-Huerta JM, Katz HR, LeBlanc PA, Hein A, Caulfield JP, Austen KF, Stevens RL (1984) Interleukin 3: a differentiation and growth factor for the mouse mast cell that contains chondrotin sulfate $\mathrm{E}$ proteoglycan. J Immunol 132:1479-1486

Shinagawa K, Kojima M (2003) Mouse model of airway remodeling. Am J Respir Crit Care Med 168:959-967. doi:10.1164/ rccm.200210-11880C

Temann UA, Geba GP, Rankin JA, Flavell RA (1988) Expression of interleukin 9 in the lungs of transgenic mice causes airway 
inflammation, mast cell hyperplasia, and bronchial hyperresponsivesness. J Exp Med 188:1307-1320

Townsend MJ, Fallon PG, Matthews DJ, Smith P, Jolin HE, McKenzie ANJ (2000) IL-9-deficient mice establish fundamental roles for IL-9 in pulmonary mastocytosis and goblet cell hyperplasia but not $\mathrm{T}$ cell development. Immunity 13:57-583. doi:10.1016/ S1074-7613(00)00056-X

Tumes DJ, Cormie J, Calvert MG, Stewart K, Nassenstein C, Braun A, Foster PS, Dent LA (2007) Strain-dependent resistance to allergen-induced lung pathophysiology in mice correlates with rate of apoptosis of lung-derived eosinophils. J Leukoc Biol 81:1362-1373. doi:10.1189/jlb.0106046

Van Hove CL, Maes T, Cataldo DD, Guéders MM, Palmans E, Joos GF, Tournoy KG (2009) Comparison of acute inflammatory and chronic structural asthma-like responses between $\mathrm{C} 57 \mathrm{BL} / 6$ and BALB/c mice. Int Arch Allergy Immunol 149:195-207. doi:10.1159/000199715

Walsh ER, Sahu N, Kearley J, Benjamin E, Kang BH, Humbles A, August A (2008) Strain-specific requirement for eosinophils in the recruitment of $\mathrm{T}$ cells to the lung during the development of allergic asthma. J Exp Med 205:1285-1292. doi:10.1084/ jem.20071836

Williams CMM, Galli SJ (2000) The diverse potential effector and immunoregulatory roles of mast cells in allergic disease. J Allergy Clin Immunol 105:847. doi:10.1067/mai.2000.106 485

Yu M, Tsai M, Tam SY, Jones C, Zehnder J, Galli SJ (2006) Mast cells can promote the development of multiple features of chronic asthma in mice. J Clin Invest 116:1633-1641. doi:10.1172/JCI25702

Zhu W, Gilmour MI (2009) Comparison of allergic lung disease in three mouse strains after systemic or mucosal sensitization with ovalbumin antigen. Immunogenetics 61:199-207. doi:10.1007/ s00251-008-0353-8

Zsebo KM, Williams DA, Geissler EN, Broudy VC, Martin FH, Atkins HL, Hsu RY, Birkett NC, Okino KH, Murdock DC (1990) Stem cell factor is encoded at the SI locus of the mouse and is the ligand for the c-kit tyrosine kinase receptor. Cell 63:213-224. doi:10.1016/0092-8674(90)90302-U 